\title{
Purification and Mode of Action of a Chitosanase from Penicillium islandicum
}

\author{
By DENNIS M. FENTON*† AND DOUGLAS E. EVELEIGH \\ Department of Biochemistry and Microbiology, Cook College, Rutgers - The State University \\ of New Jersey, New Brunswick, New Jersey 08903, U.S.A.
}

(Received 10 November 1980; revised 2 March 1981)

\begin{abstract}
Penicillium islandicum produced an inducible extracellular chitosanase when grown on chitosan. Large-scale production of the enzyme was obtained using Rhizopus rhizopodiformis hyphae as substrate. Chitosanase was purified 38 -fold to homogeneity by ammonium sulphate fractionation and sequential chromatography on DEAE-Biogel A, Biogel $\mathrm{P}_{60}$ and hydroxylapatite. Crude enzyme was unstable at $37^{\circ} \mathrm{C}$, but was stabilized by $1.0 \mathrm{~mm}-\mathrm{Ca}^{2+}$. The $\mathrm{pH}$ optimum for activity was broad and dependent on the solubility of the chitosan substrate. Various physical and chemical properties of the purified enzyme were determined.

Penicillium islandicum chitosanase cleaved chitosan in an endo-splitting manner with maximal activity on polymers of 30 to $60 \%$ acetylation. No activity was found on chitin ( $100 \%$ acetylated chitosan) or trimers and tetramers of $N$-acetylglucosamine. The latter two oligomers and all small oligomers of glucosamine inhibited the activity of chitosanase on $30 \%$ acetylated chitosan. The pentamer of $\mathrm{N}$-acetylglucosamine and glucosamine oligomers were slowly cleaved by the enzyme. Analysis of the reaction products from $30 \%$ acetylated chitosan indicated that the major oligomeric product was a trimer; with $60 \%$ acetylated chitosan as substrate a dimer was also found. The new terminal reducing groups produced by chitosanase hydrolysis of $30 \%$ acetylated chitosan were reduced by sodium boro $\left[{ }^{3} \mathrm{H}\right]$ hydride. The new end residues were found to be $N$-acetylglucosamine. The analyses strongly indicated that $P$. islandicum chitosanase cleaved chitosan between $N$-acetylglucosamine and glucosamine. Both residues were needed for cleavage, and polymers containing equal proportions of acetylated and non-acetylated sugars were optimal for chitosanase activity. The products of reaction depended on the degree of acetylation of the polymer.
\end{abstract}

\section{INTRODUCTION}

Chitin, a crystalline polymer of $N$-acetylated $(1 \rightarrow 4)$ - $\beta$-linked glucosamine residues, occurs widely in nature as a structural polymer in the integument of insects and crustacea and in the cell walls of many fungi. Chitosan, in contrast, is a non-crystalline polymer of glucosamine and $\mathrm{N}$-acetylglucosamine residues. Prior definitions of chitosan have been based on its lack of crystallinity, its high solubility in dilute acid, and its degree of acetylation. As a practical approach, we define the chitosan polymer to contain glucosamine moieties partially $N$-acetylated, with the degree (percentage) of acetylation cited. In nature, the only reported occurrence of chitosan is in the walls of a limited but medically important group of fungi, the Zygomycetes (Bartnicki-Garcia, 1968; Bruck et al., 1971; Fenton et al., 1978; Kreger, 1954; Letourneau et al., 1976; Ruiz-Herrera, 1978). These fungi are opportunistic invaders of man and can be major pathogens in burn wounds (Bruck et al., 1971). Lysis of the cell walls of these fungi was first observed by Jones et al. (1968). Subsequently, chitosanases (EC 3.2 .1 .99 ), a new class of enzymes that hydrolyse chitosan, were independently discovered by

$\dagger$ Present address: Pfizer Central Research, Eastern Point Road, Groton, Connecticut 06340, U.S.A. 
two groups: Monaghan et al. (1972) in a study of the possible use of lytic enzymes to combat pathogenic fungi, and Ruiz-Herrera \& Ramirez-Leon (1972) during a fundamental study of cell wall architecture.

Chitosanases are produced by many micro-organisms, including fungi, bacteria and actinomycetes (Monaghan et al., 1972). Crude chitosanases exhibit a wide range of substrate specificities. Enzymes acting toward chitosan have been purified to homogeneity; those from Streptomyces no. 6 (Price \& Storck, 1975) and Bacillus R-4 (Tominaga \& Tsujisaka, 1975) have been found to degrade chitosan specifically, while a polysaccharase from Myxobacter Al-1 degrades both chitosan and carboxymethylcellulose but not chitin (Hedges \& Wolfe, 1974). However, none of these reports has examined the effect of the degree of acetylation of the polymer on enzyme activity or the site of cleavage of the enzyme.

As crude extracellular preparations from Penicillium islandicum contained chitosanase, chitinase and carboxymethylcellulase activities (Monaghan et al., 1972), we proposed to purify the enzyme that degrades chitosan and to determine its substrate specificity. In addition, since naturally occurring fungal chitosans can occur with a range of degrees of acetylation (Araki \& Ito, 1974; Datema et al., 1977), it was of interest to characterize the oligomeric products of enzymic degradation of chitosan of different degrees of acetylation and to determine the effect of polymer acetylation on enzyme activity and the site of enzymic cleavage.

\section{METHODS}

Cultures. Penicillium islandicum Sopp QM7571 was obtained from Emory Simmons, Culture Collection of Fungi (QM), Department of Botany, University of Massachusetts, Amherst, Mass. Rhizopus rhizopodiformis was isolated during an autopsy performed on a patient at the Fort Sam Houston Burn Unit, U.S. Army, Houston, Texas.

Media. Penicillium islandicum was maintained on chitosan agar, which contained (g): chitosan, 1.0; $\mathrm{K}_{2} \mathrm{HPO}_{4}, 1.0 ; \mathrm{KH}_{2} \mathrm{PO}_{4}, 3.0 ; \mathrm{MgSO}_{4} .7 \mathrm{H}_{2} \mathrm{O}, 0.7 ; \mathrm{NaCl}, 0.5 ; \mathrm{CaCl}_{2}, 0.5 ;$ agar, 20 ; and distilled water to 1.01 . This is a modification of the medium of Tabata \& Terui (1962). Chitosan serves as both the carbon and nitrogen source in this medium. The chitosan was about $30 \%$ acetylated (as received) and derived by alkaline treatment of King Crab chitin (Food Chemical and Research Laboratories, Seattle, Washington). The chitosan (10X concentration) was first dissolved in $0.2 \mathrm{M}-\mathrm{HCl}$, brought to $\mathrm{pH} 5.5$ with $1.0 \mathrm{M}-\mathrm{NaOH}$, autoclaved separately, cooled to $48{ }^{\circ} \mathrm{C}$, and combined with the sterile molten salts/agar solution, which was dispensed while stirring in order to keep the chitosan in suspension.

Rhizopus rhizopodiformis was maintained on yeast/peptone/glucose medium, containing (g): yeast extract, $3 \cdot 0$; Bactopeptone (Difco), 10.0; glucose, 20.0; agar, 20.0; and distilled water to $1.0 \mathrm{l}$.

Enzyme production. Large-scale preparation of the extracellular chitosanase was accomplished by growing $P$. islandicum in the presence of Rhizopus hyphae. The Rhizopus mycelium to be used subsequently as substrate was grown in a first-stage fermenter, and $P$. islandicum was grown on the autoclaved $R$ hizopus culture in a second stage. The Rhizopus mycelium was used as a convenient source of crude chitosan, because of the lack of large quantities of commercially available purified chitosan.

Tank I. Rhizopus rhizopodiformis was grown in 7501 medium consisting of $\left(\mathrm{g} \mathrm{l}^{-1}\right)$ : cerelose (technical-grade glucose; Clinton Corn Products, Englewood Cliffs, N.J.), 20.0; $\mathrm{KH}_{2} \mathrm{PO}_{4}, 2.4 ; \mathrm{MgSO}_{4} .7 \mathrm{H}_{2} \mathrm{O}, 0.7 ; \mathrm{NaCl}, 0.6$; $\left(\mathrm{NH}_{4}\right)_{2} \mathrm{SO}_{4}, 1.0$; casein, 1.0 ; soya peptone, $5 \cdot 0$; yeast extract, 0.5 . The initial pH was adjusted to $6 \cdot 5$. Incubation was at $37^{\circ} \mathrm{C}$ with stirring ( $300 \mathrm{rev}$. $\mathrm{min}^{-1}$ ) and an airflow of $5001 \mathrm{~min}^{-1}$. After $24 \mathrm{~h}$ the $\mathrm{pH}$ was adjusted to $5 \cdot 2$. After $48 \mathrm{~h}$ the culture was autoclaved and two-thirds of the contents $(500 \mathrm{l})$ were used as the substrate for enzyme production by $P$. islandicum. Only two-thirds of the culture was used to allow for addition of 301 inoculum and to circumvent problems due to foaming.

Tank II. An inoculum of $P$. islandicum was prepared by growth in an F50 fermenter (New Brunswick Scientific Co.) containing 301 medium consisting of $\left(\mathrm{g} \mathrm{l}^{-1}\right)$ : cerelose, $20.0 ; \mathrm{KH}_{2} \mathrm{PO}_{4}, 2 \cdot 0 ;\left(\mathrm{NH}_{4}\right)_{2} \mathrm{SO}_{4}, 1 \cdot 0 ; \mathrm{NaCl}, 0.66$; $\mathrm{MgSO}_{4} .7 \mathrm{H}_{2} \mathrm{O}, 0.7$; yeast extract, 0.5 ; peptone $0 \cdot 5$. The culture was grown at $28^{\circ} \mathrm{C}$ with stirring $\left(300 \mathrm{rev} . \mathrm{min}^{-1}\right)$ and an airflow of $151 \mathrm{~min}^{-1}$ for $3 \mathrm{~d}$. This culture was transferred to tank I and $\boldsymbol{P}$. islandicum was grown with Rhizopus hyphae as substrate for $7 \mathrm{~d}$. The $\mathrm{pH}$ increased from 6.0 to 7.5 . The mycelium was removed by centrifugation in a Sharples continuous centrifuge to yield 4251 broth. The clarified broth was concentrated in a flash evaporator $\left(28^{\circ} \mathrm{C}\right)$. The resulting 281 was lyophilized and used as starting material for enzyme purification. Relatively poor yields of chitosanase $\left(0.4\right.$ units $\left.\mathrm{ml}^{-1}\right)$ were obtained in this particular large-scale production. 
Enzyme assays. Amylase, cellulase, chitinase and chitosanase activities were assayed by measuring the release of reducing sugars by the Nelson-Somogyi method (Nelson, 1944). A standard assay mixture contained 0.2 M-sodium acetate buffer pH $5.0(1.0 \mathrm{ml}), 1.0 \%$ substrate $(0.5 \mathrm{ml})$, enzyme and water to a final volume of $3.0 \mathrm{ml}$. This mixture was incubated at $37^{\circ} \mathrm{C}$ for $15-60 \mathrm{~min}$, depending on the enzyme activity, and assayed for the production of reducing sugar residues. One unit of enzyme was defined as the release of $1.0 \mu$ mol reducing sugar equivalent $\min ^{-1}$. Glucose, $N$-acetylglucosamine and glucosamine. $\mathrm{HCl}$ were used, as appropriate, for standard for amylase, cellulase, chitinase and chitosanase activities. Because the enzyme was subsequently to be evaluated as a prophylactic agent against mycotic infections, $37^{\circ} \mathrm{C}$ was used as an incubation temperature. Sodium azide (final concentration $1 \mathrm{mM}$ ) was added as a microbial inhibitor in long-term ( $>60 \mathrm{~min}$ ) incubations.

Viscometric comparisons were performed for chitosanase utilizing a Cannon $150 \mathrm{C} 188$ viscometer, with efflux time for water of $24 \mathrm{~s}$ at $37^{\circ} \mathrm{C}$. Assay mixtures were as defined for reducing sugar assays. Incubation was at $37^{\circ} \mathrm{C}$.

Protein was determined by the method of Lowry, using crystalline bovine serum albumin as the standard.

Substrates for enzyme assays. Chitosan ( $30 \%$ acetylated) was prepared for assay by dissolving flakes $(5 \cdot 0 \mathrm{~g})$ in $200 \mathrm{ml} 0.2 \mathrm{M}-\mathrm{HCl}$, adjusting to $\mathrm{pH} 5.0$ with $1.0 \mathrm{M}-\mathrm{NaOH}$, with blending, and diluting the mixture to a $1.0 \%(\mathrm{w} / \mathrm{v})$ concentration. Glycol chitosan (Wako Industries, Osaka, Japan) was dissolved in distilled water to a concentration of $1.0 \%(\mathrm{w} / \mathrm{v})$. To prepare $5 \%$ acetylated chitosan, $30 \%$ acetylated chitosan was boiled in $50 \% \mathrm{NaOH}$ under nitrogen (Horton \& Lineback, 1965).

Colloidal chitin was prepared by repeated alternate washing of chitin powder (Nutritional Biochemicals, Chagrin Falls, Ohio) with $0.1 \mathrm{M}-\mathrm{NaOH}$ and $0.1 \mathrm{M}-\mathrm{HCl}$ at $24 \mathrm{~h}$ intervals at $5{ }^{\circ} \mathrm{C}$. The cleaned chitin was suspended in a small volume of acetone, added to cold concentrated $\mathrm{HCl}$, stirred for $12 \mathrm{~h}$ at $5{ }^{\circ} \mathrm{C}$, filtered through glass wool, dialysed against several changes of water, and adjusted to $\mathrm{pH} 5.5$ with $0.1 \mathrm{M}-\mathrm{NaOH}$; the concentration was adjusted to $1.0 \%(\mathrm{w} / \mathrm{v})$.

Carboxymethylcellulose-1500 (degree of polymerization 1000; degree of substitution 15\%; 1.C.I., U.K) was dissolved in deionized water to a concentration of $1.0 \%(\mathrm{w} / \mathrm{v})$. Borohydride-reduced $\operatorname{starch}(1 \%, \mathrm{w} / \mathrm{v})$ was used as substrate for amylase assays.

Polysaccharides and glycosides were obtained from Sigma. Gifts of laminaran (from Laminaria hyperborea) from the Norwegian Seaweed Institute and pullulan (from Aureobasidium pullulans) from E. T. Reese are gratefully acknowledged. Mucoran was prepared from Rhizopus rhizopodiformis by the method of BartnickiGarcia \& Reyes (1968).

Oligomers of $N$-acetylglucosamine were prepared by the method of Rupley (1964). Glucosamine oligomers were prepared by hydrolysis of fully deacetylated chitosan with concentrated $\mathrm{HCl}$ (Horowitz et al., 1957) and the products were fractionated by using Dowex cation exchange $\left(50 \mathrm{~W}-\mathrm{X} 1 ; \mathrm{H}^{+}\right.$form) and Biogel $\mathrm{P}_{6}$ chromatography. The elution profiles of the gel filtration columns were determined using standard sugar oligomers and application of 'French-Wild' plots (French \& Wild, 1953).

Preparation of chitosans. A range of chitosans with different degrees of acetylation was prepared according to Hirano et al. (1976). Commercial chitosan derived from King Crab chitin was used as a starting material. It was about $30 \%$ acetylated. For chitosans with less than $30 \%$ acetylation, this material was first completely deacetylated (Horton \& Lineback, 1965) and reacetylated to the desired value. For the preparation of chitosans of greater than $30 \%$ acetylation, the untreated commercial material was used. Portions of $25 \mathrm{ml}$ of a $1 \%$ solution of chitosan at $\mathrm{pH} 3.5$ were diluted with $50 \mathrm{ml}$ methanol. Twice the stoichiometric amount of acetic anhydride required to yield a given percentage acetylation (i.e. $2.0 \mathrm{~mol}$ acetic anhydride per mol glucosamine) was added, with stirring. The solution was stirred overnight and the methanol and acetic acid were then removed by evaporation. The chitosans were precipitated with $1.0 \mathrm{M}-\mathrm{NaOH}$, collected by centrifugation and redissolved in 0.2 $\mathrm{M}-\mathrm{HCl}$; the $\mathrm{pH}$ was adjusted to 5.0 with $0.1 \mathrm{M}-\mathrm{NaOH}$.

Determination of the degree of acetylation of chitosan. The degree of acetylation of each chitosan was calculated by determination of glucosamine in each sample using fluorescamine (Hoffman LaRoche) (Udenfriend et al., 1972). Samples of chitosan were degraded with excess chitosanase at $37^{\circ} \mathrm{C}$ at $\mathrm{pH} 5.0$ and the mixture was then adjusted to $\mathrm{pH} 8.0$ with $0.1 \mathrm{M}-\mathrm{NaOH}$. Samples $(1 \mathrm{ml})$ containing 10,20 or $30 \mu \mathrm{g}$ chitosan were mixed with $0.5 \mathrm{ml}$ fluorescamine $\left(0.2 \mathrm{mg} \mathrm{ml}^{-1}\right)$ and the resulting fluorescence was immediately read at $475 \mathrm{~nm}$, while exciting at $390 \mathrm{~nm}$, using an Aminco Keirs Spectro-Fluorometer (American Instrument Co., Silver Springs, Maryland). The glucosamine content of the chitosan was determined by comparison with glucosamine as standard and the degree of acetylation calculated by difference. The percentage acetylation can only be determined to an approximate value $( \pm 2.0 \%)$, due to innate variability in fluorescence determinations. The percentage acetylation of chitosans of less than $50 \%$ acetylation was also determined by titration (Hayes \& Davies, 1978), which gave values in agreement with the fluorescence determinations. Samples of greater than $50 \%$ acetylation behaved like chitins when titrated. They were considerably depolymerized by the concentrated $\mathrm{HCl}$ required in the titration procedure.

Enzyme purification. All purification steps were performed at $5{ }^{\circ} \mathrm{C}$. The crude lyophilized culture broth was suspended in a minimal amount $\left(0.9 \mathrm{~g} \mathrm{ml}^{-1}\right)$ of $0.2 \mathrm{M}$-acetate buffer $\mathrm{pH} 5.0$ containing $1.0 \mathrm{~mm}^{-\mathrm{Ca}^{2+}}$ 
('concentrated culture broth' in Table 1). It formed a viscous and particulate slurry. This mixture was stirred for 1 $\mathrm{h}$, centrifuged to remove insoluble materials $(4300 \mathrm{~g}, 10 \mathrm{~min})$ and the supernatant fluid was decanted and dialysed against several changes of $1.0 \mathrm{~mm}-\mathrm{Ca}^{2+}$. The dialysed enzyme was subjected to $60-100 \%\left(\mathrm{NH}_{4}\right)_{2} \mathrm{SO}_{4}$ fractionation. The precipitate was collected by centrifugation $(3000 \mathrm{~g}, 15 \mathrm{~min})$, and resuspended in a minimal amount of $0.005 \mathrm{M}$-Tris/ $\mathrm{HCl}$ buffer $\mathrm{pH} 7.0$.

The initial recovery of the enzyme was difficult to evaluate, since the original crude enzyme gave variable activity when assayed. In some instances, recoveries of greater than $100 \%$ were achieved, presumably due to removal of inhibitory materials. Thus, no yields are reported for the $\left(\mathrm{NH}_{4}\right)_{2} \mathrm{SO}_{4}$ fractionation step (Table 1). The $\left(\mathrm{NH}_{4}\right)_{2} \mathrm{SO}_{4}$ precipitate was difficult to redissolve in buffer. Therefore, relatively large volumes were used, resulting in a slight concentration of enzyme. Isoelectric focusing of the crude enzyme showed it to have an isoelectric point of 4.2. Thus a DEAE support was chosen as the ion exchanger in purification and the chitosanase was adsorbed on DEAE-Biogel A (Bio Rad Laboratories, Richmond, California), equilibrated with $0.005 \mathrm{M}-\mathrm{Tris} / \mathrm{HCl}$ buffer $\mathrm{pH}$ 7.0. Enzyme elution was attained with a linear gradient of $\mathrm{NaCl}(0 \cdot 05-0.3 \mathrm{M}) ; 2 \mathrm{ml}$ fractions were collected. This step afforded a partial separation of chitinase and chitosanase activities.

Chitosanase fractions 65-105 were combined, lyophilized and further purified by gel filtration using Biogel $P_{60}$. The Biogel $\mathrm{P}_{60}$ column $(35 \times 3.0 \mathrm{~cm})$ was equilibrated with $0.2 \mathrm{M}$-sodium acetate buffer $\mathrm{pH} 5 \cdot 0$, and was run a flow rate of $20-30 \mathrm{ml} \mathrm{h}^{-1} ; 2 \mathrm{ml}$ fractions were collected. This step afforded a complete separation of chitinase and chitosanase activities. Fractions 25-31 were combined and lyophilized. Disc gel electrophoresis showed this chitosanase preparation to be composed of two proteins, a major chitosanase band and a minor contaminating amylase component. Chromatography on hydroxylapatite (Biogel HPT no. 13201, preswollen in 0.01 M-phosphate buffer $\mathrm{pH} 7.0$ in a $1.0 \times 15 \mathrm{~cm}$ column), with a linear gradient of $\mathrm{pH} 7.0$ phosphate buffer $(0.01-0.03 \mathrm{M})$ afforded a complete separation of chitosanase from the contaminating amylase. Fractions $21-29$ were combined.

Carbohydrate and cystine content of the purified enzyme. The purified enzyme was analysed for carbohydrate according to the method of Krystal \& Graham (1976). Chitosanase was hydrolysed in $2.0 \mathrm{M}-\mathrm{HCl}$ for $24 \mathrm{~h}$ at $100^{\circ} \mathrm{C}$. Interfering amino acids were removed by Dowex ion exchange chromatography, and sugars were analysed using ferricyanide with glucose as a standard. Cystine was determined as cysteic acid following performic acid oxidation (Hirs, 1967).

Analysis of products of chitosan degradation. Chitosanase reaction products were purified by gel filtration through Biogel $\mathrm{P}_{2}, \mathrm{P}_{6}$, or $\mathrm{P}_{10}$ columns $(90 \times 1.5 \mathrm{~cm})$. Elution was carried out at room temperature with $\mathrm{H}_{2} \mathrm{O}$ adjusted to $\mathrm{pH} 8.0$ with $0.1 \mathrm{M}-\mathrm{NaOH} ; 2 \mathrm{ml}$ fractions were collected, and products were located using fluorescamine.

Boro $\left[{ }^{3} \mathrm{H}\right]$ hydride (borotritide) reduction of reaction products. Enzyme products were prepared by reacting 100 $\mathrm{mg}$ chitosan with chitosanase overnight during dialysis against distilled water at $5^{\circ} \mathrm{C}$. The low molecular weight dialysable material was dried by lyophilization. Four of these incubations yielded $200 \mathrm{mg}$ of product. These oligomeric products $(175 \mathrm{mg})$ were dissolved in $1.0 \mathrm{ml}$ water, $\mathrm{pH} 8.0$, and reacted with $25 \mu \mathrm{Ci}$ sodium borotritide (Shiveley \& Conrad, 1970). To trap the evolved tritium gas, the reaction was performed in vacuo, with excess tritium gas being drawn off into a separate flask.

Analysis of the borotritide-reduced oligomers. The reduced oligomers were deaminated with nitrous acid and were analysed by paper chromatography. Non-reduced products, nitrous acid-treated products and standards of glucosaminitol, $\mathrm{N}$-acetylglucosaminitol, and 2-deoxyglucose were similarly compared. Solvent systems included ethyl acetate/acetic water/water $(9: 2: 2$, by vol.) and ethyl acetate/acetic acid/formic acid/water $(9: 3: 3: 1$, by vol.). After the chromatogram was developed, it was dried and cut vertically to separate the radioactive and non-radioactive products. The non-radioactive products were located using $p$-anisidine (Hough et al., 1950) or silver nitrate reagent (Trevelyan et al., 1950). The chromatogram strip containing the separated radioactive products was cut into $2.5 \mathrm{~cm}$ horizontal sections, and the activity of products in each section was determined by use of liquid scintillation, using Aqua Sol as the fluor. Counting was performed on a Beckman LS 230 scintillation counter. All samples were monitored to a standard deviation of $5.0 \%$ and an efficiency of $91 \%$.

Nitrous acid deamination. Nitrous acid deamination was performed basically according to the method of Shiveley \& Conrad (1970). A sample of 1-2 mg of the amino sugar or polymer was deaminated by incubation with $0.5 \mathrm{ml} 10 \%(\mathrm{w} / \mathrm{v})$ sodium nitrite and $0.5 \mathrm{ml} 33 \%(\mathrm{w} / \mathrm{v})$ acetic acid for $1-2 \mathrm{~h}$. The nitrous acid degradation procedure degrades glucosamine, both as a monomer and within a polymer, to 2,5-anhydromannose; it converts glucosaminitol to 2-deoxyglucose, but does not attack $N$-acetylglucosamine (Datema et al., 1977; Horton, 1969; Shiveley \& Conrad, 1970).

\section{RES ULT S}

Enzyme purification. The enzyme purification procedure yielded a 38 -fold purification, giving a chitosanase having a specific activity of 10 units $(\mathrm{mg} \text { protein })^{-1}$ (Table 1$)$. Analytical 
Table 1. Purification of P. islandicum chitosanase

$\begin{array}{ccc}\text { Specific activity* } & \begin{array}{c}\text { Overall } \\ \text { Treatment }\end{array} & \begin{array}{c}\text { Purification factor } \\ \text { at each stage }\end{array}\end{array}$

$\begin{array}{lccr}\begin{array}{l}\text { None (concentrated culture } \\ \text { broth) } \dagger\end{array} & 0.26 & 100 & - \\ \begin{array}{l}\left.\mathrm{NH}_{4}\right)_{2} \mathrm{SO}_{4}(60-100 \% \\ \text { saturation) }\end{array} & 0.8 & - & 3 \cdot 1 \\ \begin{array}{l}\text { DEAE-Biogel A } \\ \text { Lyophilization }\end{array} & 3 \cdot 3 & 72 & 4 \cdot 1 \\ \text { Biogel } \mathrm{P}_{60} & 3 \cdot 3 & 57 & 1 \cdot 0 \\ \text { Hydroxylapatite } & 10 \cdot 0 & 43 & 3 \cdot 3 \\ & 10 \cdot 1 & 42 & 1 \cdot 0 \\ & & \text { Overall purification factor } & 38.8\end{array}$

* One unit represents the release of $1.0 \mu \mathrm{mol}$ reducing sugar equivalent $\mathrm{min}^{-1}$.

+ Crude lyophilized culture broth $\left(0.9 \mathrm{~g} \mathrm{~m}^{-1}\right)$ in $0.2 \mathrm{M}$-acetate buffer pH 5.0 containing $1.0 \mathrm{mM}-\mathrm{Ca}^{2+}$ (as chloride).

$\ddagger$ Variable: see Methods.

\section{Table 2. Effect of divalent cations on chitosanase activity}

Portions $(1 \mathrm{ml})$ of dialysed crude enzyme were incubated at $37^{\circ} \mathrm{C}$ in a standard assay (see Methods) containing chitosan ( $30 \%$ acetylated) as substrate, and added cations (as chlorides) as shown. The activity of the control incubations was 0.5 units $\mathrm{ml}^{-1}$.

\begin{tabular}{ccr}
\multicolumn{2}{c}{ Added cation } & Activity (\%) \\
None & & 100 \\
$\mathrm{Ba}^{2+}$ & $10^{-3} \mathrm{M}$ & 100 \\
& $10^{-4} \mathrm{M}$ & 98 \\
& $10^{-5} \mathrm{M}$ & 100 \\
$\mathrm{Ca}^{2+}$ & $10^{-3} \mathrm{M}$ & 225 \\
& $10^{-4} \mathrm{M}$ & 200 \\
& $10^{-5} \mathrm{M}$ & 200 \\
$\mathrm{Cu}^{2+}$ & $10^{-3} \mathrm{M}$ & 0 \\
& $10^{-4} \mathrm{M}$ & 0 \\
& $10^{-5} \mathrm{M}$ & 0 \\
$\mathrm{Hg}^{2+}$ & $10^{-3} \mathrm{M}$ & 0 \\
& $10^{-4} \mathrm{M}$ & 0 \\
& $10^{-5} \mathrm{M}$ & 0 \\
$\mathrm{Mg}^{2+}$ & $10^{-3} \mathrm{M}$ & 100 \\
& $10^{-4} \mathrm{M}$ & 101 \\
& $10^{-5} \mathrm{M}$ & 103 \\
$\mathrm{Zn}^{2+}$ & $10^{-3} \mathrm{M}$ & 90 \\
& $10^{-4} \mathrm{M}$ & 100 \\
& $10^{-5} \mathrm{M}$ & 100
\end{tabular}

disc gel electrophoresis (Davis, 1964) at $\mathrm{pH} 8.2$ and 3.4 showed the purified chitosanase to be composed of a single protein (results not shown).

Effect of divalent cations on chitosanase activity. Since $P$. islandicum chitosanase was unstable in the temperature range $15-37^{\circ} \mathrm{C}$, the effect of several divalent cations $\left(\mathrm{Ba}^{2+}, \mathrm{Ca}^{2+}\right.$, $\mathrm{Cu}^{2+}, \mathrm{Hg}^{2+}, \mathrm{Mg}^{2+}$ and $\mathrm{Zn}^{2+}$, added as chlorides) on enzyme stability was examined. Only $\mathrm{Ca}^{2+}$ showed any positive stabilizing effects at $37^{\circ} \mathrm{C}$ (Table 2). Chitosanase with $\mathrm{Ca}^{2+}$ was stable for more than $48 \mathrm{~h}$, while chitosanase without $\mathrm{Ca}^{2+}$ denatured in 1-2 h. All enzyme purification was therefore routinely performed in the presence of $1.0 \mathrm{mM}-\mathrm{Ca}^{2+}$. The enzyme remained labile in the absence of $\mathrm{Ca}^{2+}$ ions following purification. Among the other ions tested, $\mathrm{Ba}^{2+}, \mathrm{Mg}^{2+}$ and $\mathrm{Zn}^{2+}$ showed no effect on enzyme activity, while $\mathrm{Hg}^{2+}$ and $\mathrm{Cu}^{2+}$ were completely inhibitory (Table 2 ). 
Table 3. Stabilization of $P$. islandicum chitosanase by $\mathrm{Ca}^{2+}$

Purified enzyme was used. Details of the procedures are given in Results. The activity of the undialysed control incubation was $0 \cdot 5$ units $\mathrm{ml}^{-1}$.

Treatment

No dialysis

EDTA dialysis

EDTA dialysis

EDTA dialysis and preincubation

for 30 min at $37^{\circ} \mathrm{C}$ without $\mathrm{Ca}^{2+}$

$$
\mathrm{Ca}^{2+} \text { in assay Activity (\%) }
$$

$\begin{array}{rr}+ & 100 \\ + & 95 \\ - & 10 \\ + & 13\end{array}$

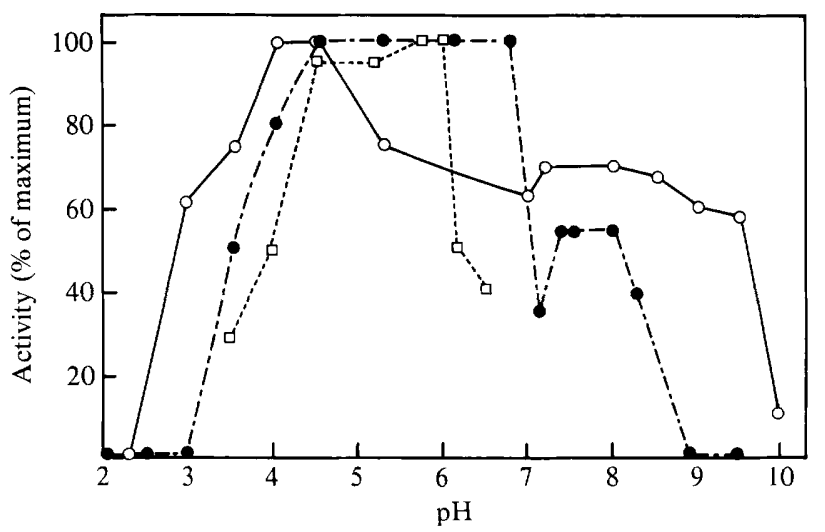

Fig. 1. pH optimum for activity and stability of $P$. islandicum chitosanase. For determination of the optimal $\mathrm{pH}$ for activity, purified enzyme diluted to $1.0 \mathrm{ml}$ with distilled water was combined with $1.5 \mathrm{ml}$ $0.5 \mathrm{M}$ buffer (sodium acetate buffer for $\mathrm{pH} 3 \cdot 6-5 \cdot 6$; sodium phosphate buffer for $\mathrm{pH} 5 \cdot 8-7 \cdot 6$; sodium

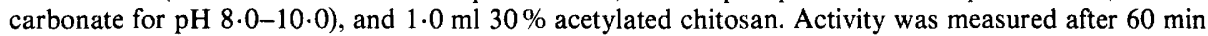
incubation at $37^{\circ} \mathrm{C}$ by the Nelson-Somogyi reducing sugar procedure. Maximum activity $(0 \cdot 1$ units $\mathrm{ml}^{-1}$ ) was equated to $100 \%$. For determination of relative stability in relation to $\mathrm{pH}$, unbuffered purified enzyme was incubated at $50^{\circ} \mathrm{C}$ for $3 \mathrm{~min}$ at various $\mathrm{pH}$ values, in the presence of $\mathrm{Ca}^{2+}$. The $\mathrm{pH}$ of the reaction mixture was then adjusted to $5 \cdot 0$, and a standard enzyme assay was run. - Activity in relation to $\mathrm{pH}$ (glycol chitosan as substrate); $\square$, activity in relation to $\mathrm{pH}(30 \%$ or $5 \%$ acetylated chitosan as substrate); $\mathrm{O}$, stability in relation to $\mathrm{pH}$ ( $30 \%$ acetylated chitosan as substrate).

To determine if $\mathrm{Ca}^{2+}$ was activating or stabilizing the chitosanase, the purified enzyme was dialysed overnight against $0.005 \mathrm{M}$-EDTA at $5{ }^{\circ} \mathrm{C}$, and then assayed for activity in the presence and absence of $\mathrm{Ca}^{2+}$. In addition, buffered chitosanase without $\mathrm{Ca}^{2+}$ or substrate was preincubated under assay conditions $\left(30 \mathrm{~min}\right.$ at $37^{\circ} \mathrm{C}$ ) and then assayed (Table 3 ). EDTA-dialysed enzyme without $\mathrm{Ca}^{2+}$, assayed in the absence of $\mathrm{Ca}^{2+}$, showed greatly reduced activity ( $10 \%$ of that of the control, undialysed enzyme). With $1.0 \mathrm{~mm}-\mathrm{Ca}^{2+}$ in the assay mixture optimal activity was maintained ( $95 \%$ of the control value). However, when the EDTA-dialysed enzyme was incubated at $37^{\circ} \mathrm{C}$ for $30 \mathrm{~min}$, and then assayed in the presence of $1.0 \mathrm{mM}-\mathrm{Ca}^{2+}$, only $13 \%$ of the initial control activity was measured. Thus $\mathrm{Ca}^{2+}$ acts to stabilize the labile enzyme at the relatively high temperature of the assay procedure. As shown in Table 2, this results in an activity of $200 \%$ of that of the unstabilized enzyme assayed at $37^{\circ} \mathrm{C}$.

Molecular weight determination. Gel filtration (Biogel $\mathrm{P}_{60}$ ) of chitosanase, in comparison with known protein standards, allowed an estimation of its molecular weight (Andrews, 1964). This was found to be approximately 30000 .

Carbohydrate content. Analysis of the carbohydrate content of the purified enzyme showed it to be less than $0.05 \mu \mathrm{g}$ per $10 \mu \mathrm{g}$ purified protein, i.e. $<0.5 \%$.

pH optimum for activity and stability. The $\mathrm{pH}$ optimum for activity of the chitosanase depended on the solubility of the chitosan. With $30 \%$ or $5 \%$ acetylated chitosan, a broad $\mathrm{pH}$ 


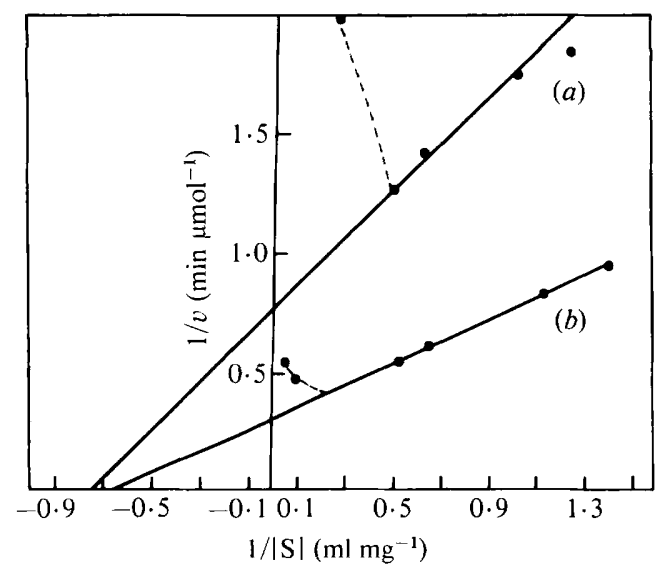

Fig. 2. Lineweaver-Burk plot of $P$. islandicum activity. Purified enzyme was diluted with 0.02 M-sodium acetate buffer $\mathrm{pH} 5.0$ and incubated for $10 \mathrm{~min}$ at $37^{\circ} \mathrm{C}$ with a range of concentrations of $5 \%$ acetylated chitosan $(a)$ or $30 \%$ acetylated chitosan $(b)$. For $5 \%$ acetylated chitosan the $K_{\mathrm{m}}$ was $1 \cdot 3$ $\mathrm{mg} \mathrm{ml} \mathrm{m}^{-1}$ and the $V_{\max }$ was $1.2 \mu \mathrm{mol} \mathrm{min} \mathrm{m}^{-1}$; for $30 \%$ acetylated chitosan the values were $1.4 \mathrm{mg} \mathrm{ml}^{-1}$ and $2.7 \mu \mathrm{mol} \mathrm{min}^{-1}$.

optimum was found between $\mathrm{pH} 4.5$ and $\mathrm{pH} 6.0$, with a rapid drop in activity below $\mathrm{pH} 4.0$ and above pH 6.5 (Fig. 1). These chitosans precipitated when the $\mathrm{pH}$ was raised to 6.5 and thus presumably became more resistant to enzymatic cleavage on precipitation. With soluble glycol chitosan as substrate, a biphasic $\mathrm{pH}$ curve was found, with maxima between $\mathrm{pH} 4.5$ and 6.8 , and $\mathrm{pH} 7.1$ and 8.0 (Fig. 1). Penicillium islandicum chitosanase was quite stable from $\mathrm{pH} 3.5$ to $\mathrm{pH} 8.5$, with optimum stability between $\mathrm{pH} 3.5$ and $\mathrm{pH} 5.5$ (Fig. 1). However, only $60 \%$ of initial activity was retained between $\mathrm{pH} 5.5$ and $\mathrm{pH} 9 \cdot 0$, under the short-term conditions tested $\left(50^{\circ} \mathrm{C}\right.$ for $\left.3 \mathrm{~min}\right)$.

Effect of substrate concentration on chitosanase activity. The effect of substrate concentration on enzyme activity was determined and is displayed as a Lineweaver-Burk plot (Fig. 2). The apparent $K_{\mathrm{m}}$ for both $5 \%$ and $30 \%$ acetylated chitosan was approximately 1.4 $\mathrm{mg} \mathrm{ml}^{-1}$ at $\mathrm{pH} 5 \cdot 2$. However, $P$. islandicum chitosanase was twice as active toward $30 \%$ acetylated chitosan $\left(V_{\max } 2.7 \mu \mathrm{mol} \mathrm{min}{ }^{-1}\right)$ as toward $5 \%$ acetylated chitosan $\left(V_{\max } 1 \cdot 2 \mu \mathrm{mol}\right.$ $\left.\min ^{-1}\right)$.

Effect of temperature on enzyme activity. The effect of temperature on activity was determined by running assays at $20,30,40,50$ and $60^{\circ} \mathrm{C}$, using $30 \%$ acetylated chitosan as substrate. Optimal activity for chitosanase, assessed from an Arrhenius plot, was found to be at $45^{\circ} \mathrm{C}$; its activation energy was $20 \mathrm{kcal} \mathrm{mol}^{-1}\left(84 \mathrm{~kJ} \mathrm{~mol}^{-1}\right)$.

Substrate specificity. The purified enzyme was specific in its degradation of chitosan. It did not degrade carboxymethylcellulose, colloidal chitin, dextran (from Leuconostoc), galactan, polygalacturonic acid, laminaran, mucoran, pectin, pullulan, salicin, xylan, $p$-nitrophenyl$\beta$-D- $N$-acetylglucosamine or $p$-nitrophenyl- $\beta$-D-glucosamine.

Effect of the degree of acetylation of chitosan on enzyme activity. The degree of acetylation of the polymer greatly affected the activity of the chitosanase (Fig. 3). The chitosan polymers most amenable to hydrolysis were $30-67 \%$ acetylated, with polymers of lower and higher degrees of acetylation being more resistant. Thus, chitosan must contain both glucosamine and $\mathrm{N}$-acetylglucosamine for optimal chitosanase activity. A bacterial chitosanase from Bacillus no. 8 prepared in our laboratory showed a similar preference (B. Davis, personal communication). However, crude Serratia chitinase (Fig. 3) and a crude chitinase from Streptomyces griseus (Monreal \& Reese, 1969) showed markedly different action patterns, only being active toward highly acetylated polymers. 


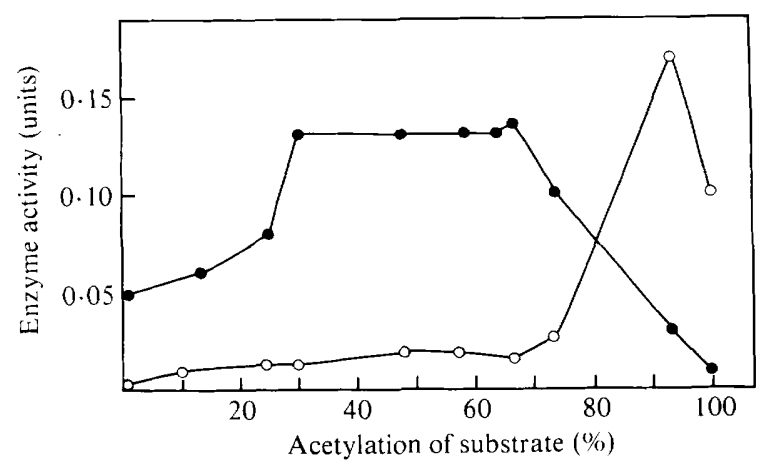

Fig. 3. Activity of $P$. islandicum chitosanase (O) and Serratia marcescens chitinase (O) in relation to the degree of acetylation of chitosan. Chitosans with differing degrees of acetylation were prepared and their susceptibility to hydrolysis was measured in a standard reaction mixture, containing either 1.0 unit of $P$. islandicum chitosanase or $S$. marcescens chitinase (see text). Serratia marcescens chitinase was obtained directly from culture broth and not purified. One unit of enzyme activity represents the release of $1.0 \mu \mathrm{mol}$ reducing sugar equivalent $\mathrm{min}^{-1}$.

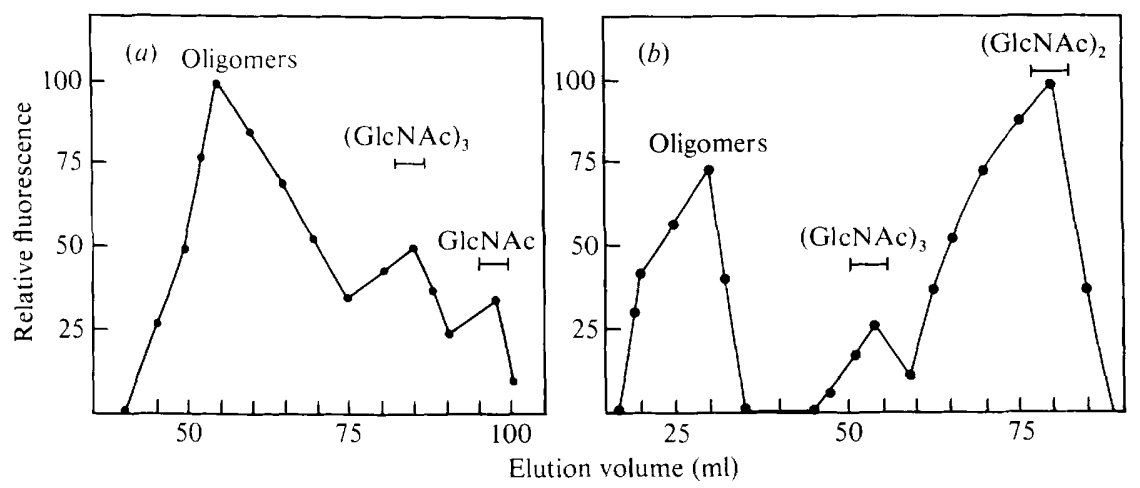

Fig. 4. Reaction products from $30 \%$ acetylated chitosan (a) and $60 \%$ acetylated chitosan (b). A 500 $\mathrm{ml}$ sample of chitosan plus excess chitosanase was incubated for $48 \mathrm{~h}$. The dialysable products were concentrated and chromatographed on a Biogel $P_{2}$ column and detected using fluorescamine. Dimer and trimer locations were defined by comparison with authentic standards of $\mathrm{N}$-acetylglucosamine.

Viscometric comparisons of chitosanase action toward each type of chitosan tested showed a rapid decrease in viscosity in all cases, except with the $5 \%$ acetylated polymers. The chitosanase slightly decreased the viscosity of soluble chitin glycol in $24 \mathrm{~h}$. Oligomeric products were detected from all chitosans tested, on analysis by paper chromatography and gel filtration.

Analysis of the products of enzymatic degradation of chitosan. (a) Gel filtration. Products of the enzymic degradation of polymers of different percentage acetylation were collected and analysed by gel filtration. Heteropolymeric standards composed of glucosamine and $N$-acetylglucosamine were not available and thus all comparisons were made with authentic oligomers of $\mathrm{N}$-acetylglucosamine. A $48 \mathrm{~h}$ digest of $30 \%$ acetylated chitosan (Fig. $4 \mathrm{a}$ ) contained a peak of higher molecular weight oligomers, a trimer peak and a smaller amount of $\mathrm{N}$-acetylglucosamine. Analysis of products from $60 \%$ acetylated chitosan again showed a peak of high molecular weight oligomers, and a dimer peak and some trimer (Fig. $4 \mathrm{~b}$ ). Chitosan substrates of $80 \%$ acetylation yielded a mixture of only high molecular weight oligomers. 
Table 4. Possible products of nitrous acid degradation of tritiated oligomeric chitosans

Tritiated oligomer reducing terminus

(A) GlcN.GlcNAc ${ }^{\text {ol* }}$

(B) GlcN $\cdot \mathrm{GlcN}^{\mathrm{O} *}$

(C) GleNAc. GleN ${ }^{\text {ol* }}$

(D) GicNAc $\cdot$ GlcNAc ${ }^{\text {ol* }}$
$\mathrm{HNO}_{2}$ degradation product

$$
\begin{aligned}
& \mathrm{M}+\mathrm{GlcNAc}^{\mathrm{ol} *} \\
& \mathrm{M}+\mathrm{dGlc} \\
& \text { GlcNAc } \cdot \text { dGlc* }^{*} \\
& \text { GlcNAc } \cdot \mathrm{GlcN}^{\text {ol* }}
\end{aligned}
$$

* Indicates the tritium label following reduction. GlcN, glucosamine; GlcN ${ }^{o l}$, glucosaminitol; GlcNAc, $N$-acetylglucosamine; GlcNAc ${ }^{\text {ol }}, N$-acetylglucosaminitol; M, 2,5-anhydromannose; dGlc, 2-deoxyglucose.

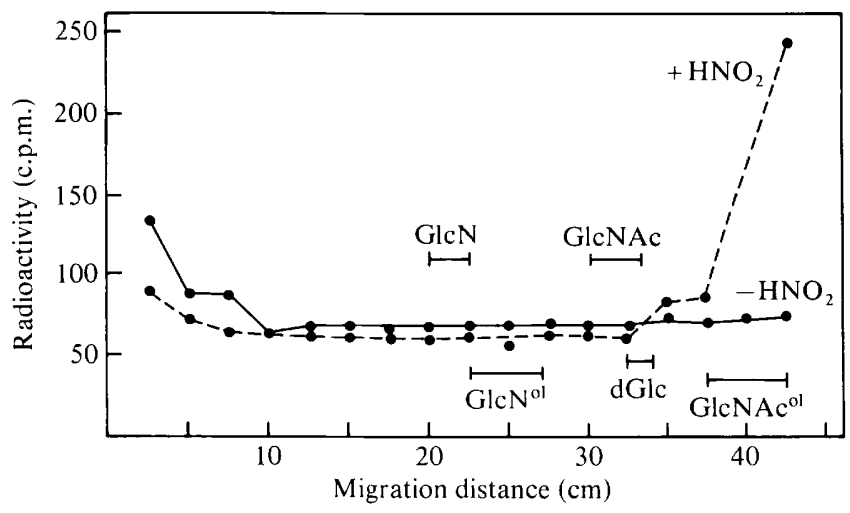

Fig. 5. Nitrous acid degradation of purified oligomer products from $30 \%$ acetylated chitosan. The enzyme products were reduced with borotritide and purified by gel chromatography, and half the samples were subjected to nitrous acid degradation. The products from the latter reaction were separated by paper chromatography and the relative migration rates of the radioactive nitrous acid products were measured by liquid scintillation. Dashed line, nitrous acid treated; continuous line, no nitrous acid treatment.

(b) Determination of the new terminal reducing residue formed by chitosanase. The new reducing residue formed by the enzyme was determined by tritium labelling of the reducing terminus of the enzyme reaction products, their subsequent degradation by nitrous acid, and chromatographic characterization. Enzymic degradation products from $30 \%$ acetylated chitosan were tritiated with borotritide and purified by repeated filtration on a Biogel $\mathbf{P}_{2}$ column. The purified 'trimer' and oligomeric peaks were collected, samples were treated with nitrous acid, and the degradation products were chromatographed.

The purified reduced oligomers can have four different dimeric sequences at their reducing termini (Table 4). If $N$-acetylglucosaminitol $\left(\mathrm{GlcNAc}^{\text {o) }}\right.$ ) were the terminal reducing sugar (A, $\mathrm{D}$ in Table 4) nitrous acid degradation of the oligomeric products would yield either $\mathrm{N}$-acetylglucosaminitol (A) or a dimer (D), as the only radioactive product. A trimer (GlcNAc. GlcNAc. GlcNAc ${ }^{\text {ol }}$ ) containing $N$-acetylglucosaminitol would also be a possible product but would be a minor component in $30 \%$ acetylated chitosan. Analysis by paper chromatography showed no radioactive $\mathrm{N}$-acetylglucosaminitol in the oligomers not treated with nitrous acid (Fig. 5). However, nitrous acid treatment released a radioactive component corresponding to $\mathrm{N}$-acetylglucosaminitol from the oligomeric product (Fig. 5). No 2-deoxyglucose (dGlc), the nitrous acid degradation product from glucosaminitol $\left(\mathrm{GlcN}^{\mathrm{ol}}\right)$, was found. As $N$-acetylglucosaminitol was released by nitrous acid degradation, $N$ acetylglucosamine (GlcNAc) was the reducing residue formed by the enzyme. Glucosamine linked to terminal glucosaminitol was not a possible major sequence, as 2 -deoxyglucose was not detected. 
Table 5. Possible products of nitrous acid degradation of tritiated trimers

Tritiated trimer

(A) GlcN. GlcN $\cdot$ GlcNol*

(B) $\mathrm{GlcN} \cdot \mathrm{GlcN} \cdot \mathrm{GlcNAc^{ \textrm {ol } * }}$

(C) GlcN.GlcNAc. GlcNol*

(D) GlcN. GlcNAc. GlcNAc ${ }^{\text {ol* }}$

(E) GlcNAc. GlcN $\cdot$ GlcNAc $^{\text {ol* }}$

(F) GlcNAc. GlcN. GlcN ${ }^{\text {ol* }}$

(G) GlcNAc· GlcNAc. GlcN ${ }^{\text {ol* }}$

(H) GlcNAc. GlcNAc. GlcNAc ${ }^{\text {ol* }}$
$\mathrm{HNO}_{2}$ degradation product

$$
\begin{aligned}
& \mathbf{M}+\mathbf{M}+\mathrm{dGlc}^{*} \\
& \mathrm{M}+\mathrm{M}+\mathrm{GlcNAc}^{\mathrm{ol} *} \\
& \mathrm{M}+\mathrm{GlcNAc} \cdot \mathrm{dGlc} \text { * } \\
& \mathrm{M}+\mathrm{GlcNAc} \cdot \mathrm{GlcNAc}^{\text {ol* }} \\
& \text { GlcNAc } \cdot \mathrm{M}+\text { GlcNAc }^{\text {ol* }} \\
& \text { GlcNAc } \cdot M+\text { dGlc}^{*} \\
& \text { GlcNAc - GlcNAc - dGlc* }
\end{aligned}
$$

* Indicates the tritium label following reduction. Abbreviations as for Table 4.

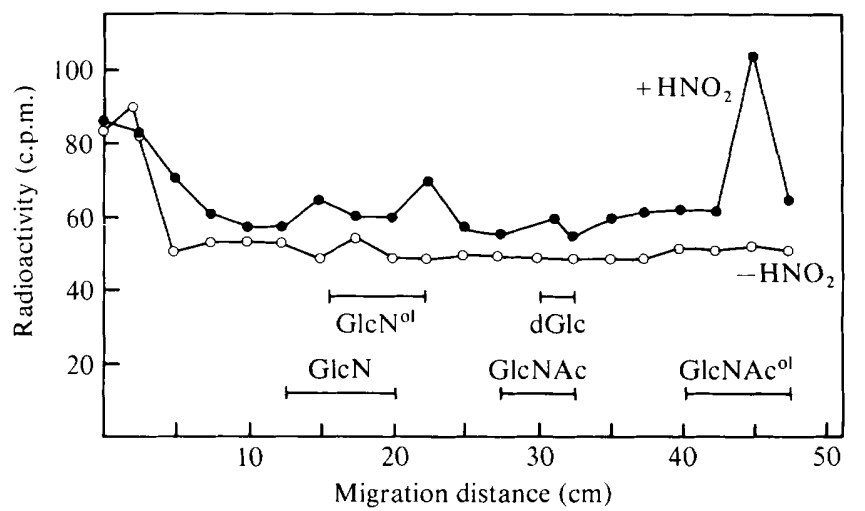

Fig. 6. Nitrous acid degradation of purified 'trimer' product from $30 \%$ acetylated chitosan. The borotritide-reduced 'trimer' was purified by gel chromatography, and half the samples were subjected to nitrous acid degradation. The products of the reaction were separated by paper chromatography and their relative migration rates were measured by liquid scintillation. $O$, Nitrous acid treated; $O$, no nitrous acid treatment.

For further clarification of the enzyme's site of cleavage, the reducing termini of the purified trimers were also analysed. The eight possible trimer sequences and nitrous acid degradation products are listed in Table 5. Sequences $B, C$, and $F$ are the most probable with a $30 \%$ acetylated polymer. If $N$-acetylglucosamine is the only reducing residue in the trimer peak (e.g. $B$ ), treatment with nitrous acid will show $N$-acetylglucosaminitol to be the only radioactive monomer formed. Paper chromatography showed that nitrous acid treatment of the trimer released $N$-acetylglucosaminitol and no 2-deoxyglucose (Fig. 6). Thus, sequence $B$ $\left(\mathrm{GlcN} \cdot \mathrm{GlcN} \cdot \mathrm{GlcN}^{\mathrm{ol}}{ }^{\mathrm{ol}}\right)$ and sequence $E\left(\mathrm{GlcNAc} \cdot \mathrm{GlcN} \cdot \mathrm{GlcNAc}^{\mathrm{ol}}\right)$ are the most probable sequences in the trimer. In either case, the enzyme cleaves the polymer at an $N$ acetylglucosamine unit.

Sequence of the purified trimer derived from $30 \%$ acetylated chitosan. A trimer composed of $\mathrm{GlcN} \cdot \mathrm{GlcN} \cdot \mathrm{GlcNAc}^{\mathrm{ol}}$ ( $B$ in Table 5) is degraded to 2,5-anhydromannose (M) and $N$-acetylglucosamine by nitrous acid treatment. Other combinations that could be formed with $N$-acetylglucosamine as the terminal reducing residue would not be degraded (GlcNAc. GlcNAc - GlcNAc), or would be degraded to a monomer and a dimer (GlcNAc - M + GlcNAc or M + GlcNAc. GlcNAc). Paper chromatography of the products of nitrous acid treatment of the purified trimer product showed only $\mathrm{N}$-acetylglucosamine and 2,5anhydromannose to be formed, indicating that the sequence of the trimer is GlcN.GlcN.GlcNAc (results not shown). It should be noted that standard 2,5anhydromannose is unstable and degrades rapidly. It was necessary to repeat this experiment several times in order to obtain satisfactory separation of the standards. 
Table 6. Oligomers as substrates and inhibitors of chitosanase activity

For the substrate tests, the oligomers were used at $10 \mathrm{mg} \mathrm{ml}^{-1}$. Substrate degradation is expressed as a percentage of that obtained in a standard assay with $30 \%$ acetylated chitosan as substrate. For the inhibitor tests, the oligomers were used at $1.0 \mathrm{mg} \mathrm{ml}^{-1}$ in a standard $15 \mathrm{~min}$ assay with $30 \%$ acetylated chitosan as substrate and 0.5 unit of enzyme. The activity of the control incubation was $0 \cdot 5$ units $\mathrm{ml}^{-1}$.

Oligomer Degradation of

\begin{tabular}{|c|c|c|}
\hline Oligomer & substrate (\%) & \\
\hline$(\mathrm{GlcNAc})_{3}$ & 0 & 22 \\
\hline$(\mathrm{GlcNAc})_{4}$ & 0 & 15 \\
\hline$(\mathrm{GlcNAc})_{5}$ & 1 & 20 \\
\hline$(\mathrm{GlcN})_{3-}$ & 61 & 30 \\
\hline GleN $\cdot$ GleN . GlcNAc & 0 & 100 \\
\hline GlcN & NT & 51 \\
\hline GlcNAc & NT & 5 \\
\hline
\end{tabular}

NT, Not tested.

Effect of small oligomers on enzyme activity. Purified oligomers of $N$-acetylglucosamine were tested for their ability to act as substrates (at $10 \mathrm{mg} \mathrm{ml}^{-1}$ ) or inhibitors (at $1 \mathrm{mg} \mathrm{m}^{-1}$ ) for $P$. islandicum chitosanase (Table 6). The trimer and tetramer of $N$-acetylglucosamine were not substrates for the enzyme. These oligomers inhibited chitosanase cleavage of $30 \%$ acetylated chitosan by $15-25 \%$ when they were present in a standard assay mixture. The pentamer of $\mathrm{N}$-acetylglucosamine inhibited chitosanase action by $20 \%$, but was also a poor substrate for the enzyme, being 100 -fold more resistant to hydrolysis than $30 \%$ acetylated chitosan. A mixture of oligomers of glucosamine $\left(1.0 \mathrm{mg} \mathrm{ml}^{-1}\right)$ inhibited chitosanase activity by $30 \%$. Upon long incubation $(24 \mathrm{~h})$ with the enzyme, these glucosamine oligomers were slowly degraded.

Thus, it would appear that both $\mathrm{N}$-acetylglucosamine and glucosamine oligomers are capable of binding to chitosanase, inhibiting its action. It also appears that both $\mathrm{N}$-acetylglucosamine and glucosamine are necessary within the polymer for optimal enzyme action (Fig. 3, Table 6). It is unfortunate that standard hetero-oligomers containing both glucosamine and $\mathrm{N}$-acetylglucosamine were not available for testing. However, one such oligomer was prepared-the trimer product GlcN . GlcN · GlcNAc-from hydrolysis of $30 \%$ acetylated chitosan. This oligomer was not a substrate for chitosanase, even upon long incubation with highly concentrated enzyme solution. However, at $1.0 \mathrm{mg} \mathrm{ml}^{-1}$ it completely inhibited the enzyme's action toward $30 \%$ acetylated chitosan (Table 6 ).

\section{DISCUS SION}

The $P$. islandicum chitosanase was purified 38 -fold, with retention of $40 \%$ of initial activity, by $\left(\mathrm{NH}_{4}\right)_{2} \mathrm{SO}_{4}$ fractionation and sequential chromatography on DEAE-Biogel A, Biogel $\mathrm{P}_{60}$ and hydroxylapatite. It was found to be a relatively small acidic protein, having a molecular weight of 30000 , a pI of $4 \cdot 2$, and, with $30 \%$ acetylated chitosan as substrate, a $K_{\mathrm{m}}$ of $1.4 \mathrm{mg}$

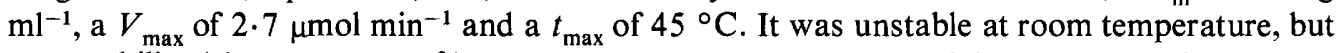
was stabilized by $1.0 \mathrm{mM}-\mathrm{Ca}^{2+}$. The effect of $\mathrm{pH}$ on enzyme activity was dependent on the substrate used. With soluble chitosan of $5 \%$ and of $30 \%$ acetylation, a pH optimum of 4.5 to 6.0 was found. These soluble chitosans precipitate near $\mathrm{pH} 6.5$, and thus presumably become more resistant to enzymatic cleavage. It should also be noted that $\mathrm{Ca}^{2+}$ in phosphate buffer would become insoluble at these higher $\mathrm{pH}$ values. Whether this loss of $\mathrm{Ca}^{2+}$ from solution would result in a decrease in the stabilizing action of this ion on the enzyme is unknown. The use of a buffer other than phosphate at alkaline $\mathrm{pH}$ may favour solution of $\mathrm{Ca}^{2+}$ ion and may increase the stability and activity of chitosanase at alkaline pH. With glycol chitosan, a 
Table 7. Microbial chitosanases

\begin{tabular}{|c|c|c|c|c|c|}
\hline & $\begin{array}{l}\text { Penicillium } \\
\text { islandicum }\end{array}$ & $\begin{array}{l}\text { Streptomyces } \\
\text { no. } 6\end{array}$ & $\begin{array}{c}\text { Myxobacter } \\
\text { Al-1 }\end{array}$ & $\begin{array}{l}\text { Bacillus } \\
\quad \text { R4 }\end{array}$ & $\begin{array}{l}\text { Bacterium } \\
\mathrm{K}-1\end{array}$ \\
\hline \multicolumn{6}{|l|}{ Specificity } \\
\hline Chitosan & + & + & + & + & + \\
\hline Chitin & - & - & - & - & - \\
\hline CM-cellulose & - & - & + & NT & + \\
\hline $\begin{array}{l}\text { Action: endo- or } \\
\text { exo-splitting }\end{array}$ & Endo & Endo & Endo & NT & Endo \\
\hline $\begin{array}{l}\text { Constitutive (C) or } \\
\text { inducible (I) }\end{array}$ & I & I & $\mathrm{C}$ & $\mathrm{C}$ & I \\
\hline Mol. wt & 30000 & 30000 & $\begin{array}{l}28900^{*} \\
31000^{\dagger}\end{array}$ & NT & 50000 \\
\hline Stability at $37^{\circ} \mathrm{C}$ & $\begin{array}{c}\text { Stable } \\
\left(+1 \mathrm{mM}-\mathrm{Ca}^{2+}\right)\end{array}$ & Unstable & $\pm \ddagger$ & Stable & Stable \\
\hline \multicolumn{6}{|l|}{ Optimum pH } \\
\hline Chitosan & $4 \cdot 5-6 \cdot 0$ & $7 \cdot 5$ & 5.0 and 6.8 & $7.6 \S$ & $5 \cdot 5-6 \cdot 9$ \\
\hline CM-cellulose & NA & NA & $5 \cdot 0$ & NT & $5 \cdot 0$ \\
\hline $\begin{array}{l}\text { Zygomycete protoplasts } \\
\text { released by crude } \\
\text { enzyme }\end{array}$ & + & + & + & + & + \\
\hline Reference & This study & $\begin{array}{c}\text { Price \& } \\
\text { Storck (1975) }\end{array}$ & $\begin{array}{c}\text { Hedges \& } \\
\text { Wolfe (1974) }\end{array}$ & $\begin{array}{c}\text { Tominaga \& } \\
\text { Tsujisaka (1975) }\end{array}$ & $\begin{array}{c}\text { B. Davis } \\
\text { (pers. comm.) }\end{array}$ \\
\hline \multicolumn{6}{|c|}{$\begin{array}{l}\text { NT, Not tested; NA, not applicable. } \\
\text { * From amino acid composition. } \\
\text { † From gel filtration analysis. }\end{array}$} \\
\hline
\end{tabular}

substrate soluble over a wide $\mathrm{pH}$ range, a biphasic curve was seen. The biphasic response of $P$. islandicum chitosanase to $\mathrm{pH}$ using glycol chitosan as substrate is similar to that exhibited by Myxobacter Al-1 chitosanase (Hedges \& Wolfe, 1974), although 5.0\% acetylated chitosan was used as a substrate in the latter case and would have been precipitated in colloidal state above $\mathrm{pH} 6 \cdot 5$.

A comparison of $P$. islandicum chitosanase with the other known chitosanases is presented in Table 7. They are all extracellular, although an intracellular chitosanase, presumably involved in cell wall modification, has been demonstrated in Rhizopus rhizopodiformis (Monaghan et al., 1972). Both inducible and constitutive forms are known. All four purified chitosanases have molecular weights of approximately 30000 or 50000 . The mode of action of all chitosanases is apparently endo-splitting (Fenton et al., 1978). There are no apparent similarities in the amino acid composition of the two chitosanases analysed (Hedges \& Wolfe, 1974; Price \& Storck, 1975). It is noteworthy that both the Streptomyces and the $P$. islandicum chitosanase contain no cystine, and yet inhibition by $\mathrm{Hg}^{2+}$ was found with both enzymes. One possibility is that since chitosan has a well-documented chelation capacity (Muzzarrelli, 1973, 1977), $\mathrm{Hg}^{2+}$ could be associating with the polymer and sterically inhibiting chitosan cleavage (Storck \& Price, 1977).

Purified $P$. islandicum chitosanase degrades chitosan specifically. It does not act on chitin or carboxymethylcellulose. It cleaves chitosans of 30-60\% acetylation with maximal activity (Fig. 3). Thus, both glucosamine and $N$-acetylglucosamine are necessary for optimal activity. The highly acetylated chitosans, chitin and chitosans of low acetyl content appear to be poor 
substrates because they contain either insufficient $\mathrm{N}$-acetylglucosamine or insufficient glucosamine residues for optimal activity. However, glycol chitin, the pentamer of $\mathrm{N}$-acetylglucosamine, and oligomers of glucosamine are all slowly hydrolysed by chitosanase over a $24 \mathrm{~h}$ incubation period, indicating that cleavage of these homo-polymers can occur, but at a much reduced rate (Table 6).

The role of a chitosanase with greatest reactivity toward $30-60 \%$ acetylated chitosan is intriguing. Early studies implied that naturally occurring chitosan of Mucorales is a fully deacetylated polymer (Bartnicki-Garcia \& Nickerson, 1962). Subsequent work has demonstrated chitosan to be partially acetylated in the cell wall of Mucor mucedo (Datema $e t$ al., 1977) and $M$. rouxii (Davis \& Bartnicki-Garcia, 1980). Highly acetylated chitosans could also occur in the walls of Mucorales following partial deacetylation of chitin (Araki \& Ito, 1974), but no such chitosans have yet been reported.

Chitosan has been used as substrate for the characterization of crude chitinase preparations (Tracey, 1955; Vessey \& Pegg, 1973). The use of chitosan in these instances is inappropriate since chitinase from Serratia (Fig. 3), Streptomyces sp. (results not shown) and Streptomyces griseus (Hirano \& Yagi, 1980) show no activity toward chitosan. The activities observed using chitosan as a substrate for chitinase may reflect the presence of specific chitosanases in the crude preparations. There may be chitosanase-chitinase enzymes with broad specificity, but until this point is defined the use of chitosan as a substrate for chitinase is ill-advised.

The new terminal reducing groups of the reaction products from $30 \%$ acetylated chitosan were identified by tritiation of the reducing groups with sodium borotritide and subsequent analysis of the products of deamination with nitrous acid. $N$-Acetylglucosamine was shown to be the terminal reducing residue of the products (Figs 4, 5 and 6). The results of these analyses can be most simply explained if the enzyme cleaved the polymer optimally at those sequences where $N$-acetylglucosamine was linked by its reducing moiety to a glucosamine. That is, the enzyme cleaved the polymer to form $N$-acetylglucosamine as the new reducing terminus (Figs 5 and 6), but could not readily cleave the bond between two adjacent $N$-acetylglucosamine residues (Table 6, Fig. 7). A $30 \%$ acetylated polymer would contain, on the average, one acetylated sugar per three residues. A trimer composed of GlcN. GlcN . GlcNAc could be a major product of enzymic degradation, and this trimer appeared as a product (Fig. $4 a$ ). A $60 \%$ acetylated polymer should contain $\mathrm{N}$ acetylglucosamine approximately every other residue, and this a dimer of glucosamine and $\mathrm{N}$-acetylglucosamine (GlcN. GlcNAc) should be a major product; and a dimer product was found (Fig. $4 \mathrm{~b}$ ). Chitosan of $80 \%$ acetylation, a chitin-like polymer which was a poor substrate for chitosanase, could be cleaved at only two out of every ten residues, consequently releasing large oligomers. All our results indicate preferred cleavage to occur between $\mathrm{N}$-acetylglucosamine and glucosamine residues. Cleavage at other sites would yield distinct products not found in this study (Fig. 7).

Inhibition of activity by trimers and tetramers of $\mathrm{N}$-acetylglucosamine, and the slow cleavage of the pentamer, indicate that the minimum chain length for cleavage is probably at least five residues (Table 6). However, since these oligomers lack glucosamine, they were not ideal substrates for the enzyme. Unfortunately, no oligomers of greater than three residues and containing both glucosamine and $\mathrm{N}$-acetylglucosamine residues were available to test their relative effects.

How does one define chitosanase and distinguish it from other glycosidases? Because chitinases have been defined as enzymes which act against chitin and yield products with $\mathrm{N}$-acetylglucosamine terminal residues (Muzzarrelli, 1977), the initial simple concept of a 'chitosanase' was of a glycosidase that would hydrolyse chitosan to yield glucosamine terminal residues. However, $P$. islandicum chitosanase does not fit this concept since it preferentially releases $\mathrm{N}$-acetylglucosamine terminal reducing moieties. It differs from chitinase in showing essentially no activity toward chitin, though it will react slowly with small chitin oligomers. Chitosanases that release terminal glucosamine residues may well exist, for 

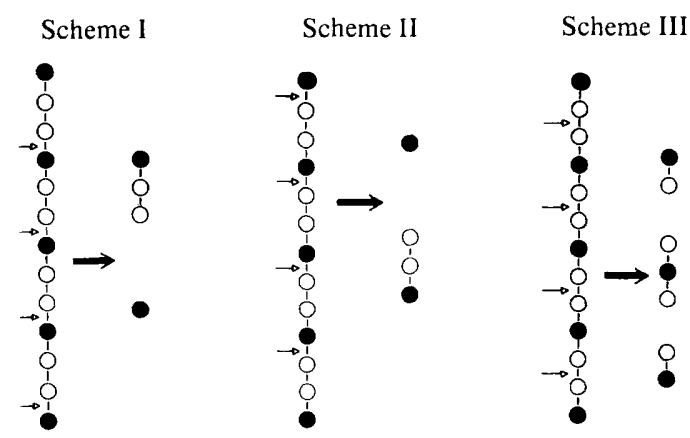

- $N$-Acetylglucosamine

o Glucosamine

Fig. 7. Three idealized schemes for the enzymic degradation of $30 \%$ acetylated chitosan. A regular repeating unit is used for simplicity. Only scheme I yields $N$-acetylglucosamine as the reducing terminus. Schemes II and III yield oligomers with reducing terminal glucosamine, which were not found in this study. Only scheme I is consistent with the observation that no 2-deoxyglucose (the nitrous acid degradation product of glucosamine) was detected in this study. The small arrows indicate cleavage sites.

instance the specific chitosanases from Streptomyces (Price \& Storck, 1975) and Bacillus (Tominga \& Tsujisaka, 1975), but their site of cleavage has not yet been determined. Furthermore, as older cell walls of Mucorales contain chitosans with relatively low degrees of acetylation (5-30\%; unpublished results), they could well be susceptible to intracellular chitosanases (Monaghan et al., 1972), which have glucosamine residues as their sites of attack. The recent techniques that allow preparation of chitosans with a range of defined degrees of acetylation allow further study of this interesting grouping of enzymes.

Why did chitosanases of differing specificity evolve? Schindler et al. (1977) have hypothesized that 'evolutionary changes in substrate structure may have influenced the development of the active site of lysozyme so that it could function most efficiently with the particular natural substrate encountered by each species'. The chitosan of Mucorales exhibits a range of degrees of acetylation (Araki \& Ito, 1974; Bartnicki-Garcia, 1980) and a range of chitosans is probably produced in the environment through deacetylation in the recycling of chitin (unpublished observation). Thus, similar evolutionary pressure may be postulated for 'chitosanases', leading to the development of enzymes having differing specificities.

This work was supported by grants from the U.S. Army (DA-ARO-D-31-124-73-GI54), the National Oceanographic and Aeronautics Administration and the Rutgers University Biomedical Science Committee and was performed as a part of NJAES Project No. 515, supported by the New Jersey Agricultural Experiment Station.

Journal paper of the New Jersey Agricultural Experiment Station, Rutgers - The State University of New Jersey, New Brunswick, New Jersey 08903, U.S.A.

\section{REFERENCES}

ANDREws, P. (1964). Estimation of the molecular weights of proteins by Sephadex gel filtration. Biochemical Journal 91, 222-233.

ARAKI, Y. \& ITo, E. (1974). A pathway of chitosan formation in Mucor rouxii: enzymatic deacetylation of chitin. Biochemical and Biophysical Research Communications 56,669-675.

BARTNICKI-GarCIA, S. (1968). Cell wall composition and other biochemical markers in fungal phylogeny. Annual Review of Microbiology 22, 87-108.

BARTNICKI-GARCIA, S. \& NiCKERSON, W. J. (1962). Isolation, composition and structure of cell walls of filamentous and yeast-like forms of Mucor rouxii.
Biochimica et biophysica acta 58, 102-119.

BARTNICKI-Garcia, S. \& ReYes, E. (1968). Polyuronides in the cell walls of Mucor rouxii. Biochimica et biophysica acta 170, 54-62.

Bruck, H. M., Nash, G., Foley, F. D. \& Pruitt, B. A., JR (1971). Opportunistic fungal infections of the burn wound with Phycomyces and Aspergillus. Archives of Surgery 102, 476-482.

Datema, R., Wessels, J. G. H. \& Van Den Ende, H. (1977). The hyphal wall of Mucor mucedo: hexosamine-containing polymers. European Journal of Biochemistry 80, 621-626.

DAvis, B. J. (1964). Disc gel electrophoresis. II. 
Method and application to human serum proteins. Annals of the New York Academy of Sciences 121, 404-409.

Davis, L. \& Bartnicki-Garcia, S. (1980). The structure and biosynthesis of chitosan from Mucor rouxii. Abstracts, Mycological Society of America, no. $\mathrm{C} 27$.

Fenton, D. M., Davis, B., Rotgers, C. \& Eveleigh, D. E. (1978). Enzymatic hydrolysis of chitosan. In First International Symposium on Chitin and Chitosan, pp. 525-541. Edited by R. A. A. Muzzarrelli \& E. R. Pariser. Boston: MIT Press.

FrenCH, D. \& WILD, G. M. (1953). Correlation of carbohydrate structure with papergram mobility. Journal of the American Chemical Society 75, 2612-2616.

Hayes, R. \& Davies, D. H. (1978). Characterization of chitosan. II. The determination of the degree of acetylation of chitosan and chitin. In First International Symposium on Chitin and Chitosan, pp. 406-420. Edited by R. A. A. Muzzarrelli \& E. R. Pariser. Boston: MIT Press.

Hedges, A. \& Wolfe, R. S. (1974). Extracellular enzyme from Myxobacter Al-1 that exhibits both $\beta$-1,4-glucanase and chitosanase activities. Journal of Bacteriology 120, 844-853.

HiRano, S. \& Yagi, Y. (1980). The effects of $\mathrm{N}$-substitution on chitosan and the physical form of the products on the rate of hydrolysis by chitinase from Streptomyces griseus. Carbohydrate Research 83, 103-108.

Hirano, S., Ohe, Y. \& Ono, H. (1976). Selective $N$-acetylation of chitosan. Carbohydrate Research 47, 315-320.

Hirs, C. H. W. (1967). Determination of cystine as cysteic acid. Methods in Enzymology 2, 59-62.

Horowitz, S. T., Roseman, S. \& Blumenthal, H. (1957). The preparation of glucosamine oligosaccharides. I. Separation. Journal of the American Chemical Society 79, 5046-5049.

HoRTON, D. (1969). Monosaccharide amino sugars. In The Amino Sugars, vol. 1A, p. 128. Edited by R. W. Jeanloz. New York: Academic Press.

Horton, D. \& LinebACK, D. R. (1965). NDeacetylation: chitosan from chitin. Methods in Carbohydrate Chemistry, 403-406.

Hough, L., Jones, J. K. N. \& Wadman, W. H. (1950). Quantitative analysis of mixtures of sugars by the method of partition chromatography. V. Improved methods for the separation and detection of the sugars and their methylated derivatives on the paper chromatogram. Journal of the Chemical Society, 1702-1706.

Jones, D., Bacon, J. S. D., FARmer, V. C. \& Webley, D. M. (1968). Lysis of the cell walls of Mucor ramannianus Moller by a Streptomycete sp. Antonie van Leeuwenhoek 35, 173-182.

KREGER, D. R. (1954). Observations of cell walls of yeast and some other fungi by $\mathrm{X}$-ray diffraction and solubility tests. Biochimica et biophysica acta 13, 1-9.

Krystal, G. \& Graham, A. F. (1976). A sensitive method for estimating the carbohydrate content of glycoproteins. Analytical Biochemistry 57, 336-345.

Letourneau, D. R., Deven, J. M. \& Manocha, M. S. (1976). Structure and composition of the cell wall of
Choanephora curcurbitarum. Canadian Journal of Microbiology 22, 486-494.

Monaghan, R. L., Eveleigh, D. E., Tewari, R. \& REESE, E. T. (1972). Chitosanase, a novel enzyme. Nature New Biology 245, 79-81.

Monreal, J. \& Reese, E. T. (1969). The chitinase of Serratia marcescens. Canadian Journal of Microbiology 15, 689-696.

Muzzarrelli, R. A. A. (1973). Chitosan. In Natural Chelating Polymers, pp. 144-176. New York: Pergamon Press.

Muzzarrelli, R. A. A. (1977). Chitin, pp. 155-181. New York: Pergamon Press.

Nelson, W. (1944). A photometric adaptation of the Somogyi method for determination of glucose. Journal of Biological Chemistry 153, 375-380.

PRICE, J. S. \& STORCK, R. (1975). Production, purification and characterization of an extracellular chitosanase from Streptomyces. Journal of Bacteriology 124, 1574-1585.

Ruiz-Herrera, J. (1978). The distribution and quantitative importance of chitin in fungi. In First International Symposium on Chitin and Chitosan, pp. 11-12. Edited by R. A. A. Muzzarrelli \& E. R. Pariser. Boston: MIT Press.

Ruiz-Herrera, J. \& RAMirez-Leon, I. F. (1972). Purification of chitosanases active against the cell walls of Mucorales. Abstract, Third International Symposium on Yeast Protoplasts.

Rupley, J. A. (1964). The hydrolysis of chitin by concentrated hydrochloric acid and the preparation of low molecular weight substrates for lysozyme. Biochimica et biophysica acta 83, 245-255.

Schindler, M., Mirelman, D. \& Sharon, S. (1977). Substrate-induced evolution of lysozymes. Biochimica et biophysica acta 482, 386-392.

Shiveley, J. E. \& ConRad, H. E. (1970). Stoichiometry of the nitrous acid deaminative cleavage of model amino sugar glucosides and glucosaminoglycuronans. Biochemistry 9, 33-43.

STORCK, R. \& PrICE, J. S. (1977). Sensitivity of germinating spores of Mucor rouxii to chitosanase. Experimental Mycology 1, 323-338.

TABATA, S. \& TeruI, G. (1962). Studies on microbial enzymes active in hydrolyzing yeast walls. I. Isolation of a strain and culture conditions for enzyme formation. Journal of Fermentation Technology 40, 366-373.

Tominaga, Y. \& Tsujisaka, Y. (1975). Purification and some enzymatic properties of the chitosanase from Bacillus R-4 which lyses Rhizopus cell walls. Biochimica et biophysica acta 410, 145-155.

Tracey, M. V. (1955). Chitin. In Modern Methods of Plant Analysis, vol. II, pp. 264-274. Edited by K. Paech and M. V. Tracey. Berlin: Springer-Verlag.

Trevelyan, W. E., Proctor, D. P. \& Harrison, J. S. (1950). Detection of sugar on paper chromatograms. Nature, London 166, 444-445.

Udenfriend, J., Stien, J., Bohlen, P. \& Dairman, W. (1972). Fluorescamine as a reagent for assay of amino acids, peptides, proteins and primary amines in picomole range. Science 178, 871 .

Vessey, J. C. \& PegG, G. P. (1973). Autolysis and chitinase production in cultures of Verticillium alboatrum. Transactions of the British Mycological Society 60, 133-143. 